\title{
ISOLATION AND GENOMIC IDENTIFICATION OF SALMONELLA PULLORUM IN THE MAJOR POULTRY FARMS OF NEPAL
}

\author{
D. R. Khanal ${ }^{*}$, R. Pokhrel $^{2}$, N. Bajracharya ${ }^{2}$, S. Khanal $^{2}$ and P. Shrestha ${ }^{1}$ \\ ${ }^{1}$ Animal Health Research Division, NARC, Khumaltar, Lalitpur \\ ${ }^{2}$ SAAN International College, Gairidhara, Kathmandu \\ (*email: drkhanal7@gmail.com)
}

\begin{abstract}
In the present study, Salmonella pullorum bacteria were isolated from 30 liver samples of poultry collected during the postmortem examination of suspected cases of pullorum disease from five major poultry producing districts (Kathmandu, Lalitpur, Bhaktapur, Kavre and Chitwan) of central Nepal in 2014. After isolating bacterial colonies from 30 samples in Brilliant Green Agar (BGA) and Xylose Lysine Deoxycholate (XLD) agar media, biochemical tests carried out for the identification of bacteria. On carbohydrate fermentation tests, 25 isolates showed metabolic characteristics typical for Salmonella while genomic analysis performed with Polymerase Chain Reaction (PCR) by amplifying Salmonella pullorum specific rfbs gene (187 bp) targeting Adenine residue at 237 positions confirmed that 18 isolates were from poultry suffering from pullorum disease. Present result warranted the need for routine biochemical and genomic investigations for better understanding of the species of Salmonella prevalent and subsequent adoption of suitable control strategy in the poultry operation.
\end{abstract}

Keywords: Salmonella pullorum, biochemical tests, PCR, $r f b s$ gene

\section{INTRODUCTION}

Pullorum disease in poultry is one of the important bacterial diseases causing insidious economic losses and having great implication on food security. In Nepal, the economic loss incurred by Salmonellosis in poultry operation is very high. Pullorum diseaseis caused by Salmonella enteric subspecies serovar Gallinarum biovar pullorum (Salmonella pullorum) (Brooks et al.,2008). The sites of predilection of these Gram-negative bacteria in birds are liver, spleen and reproductive tract. The symptoms of pullorum disease are inappetance, depression, ruffled feathers, closed eyes, loud chirping, white diarrhoea, vent pasting, gasping, lameness in chicks and severe drop in egg production in layers.

Various selective and non-selective enrichment methods are used for the isolation of Salmonella bacteria (OIE 2012) while biochemical tests (WHO Global Food-borne Infections Network, 2010), classical carbohydrate fermentation tests (Nordic Committee on Food Analysis 1999) and PCR of the bacterial genomic DNA (Cha et al., 2008) are used to identify the bacteria. The colonies showing typical characteristics of Salmonella are subjected to biochemical tests that describe the metabolic activity of particular microorganism; it therefore, serves as a confirmatory test for the isolated bacteria. Salmonella pullorum unlike other Salmonella species ferment glucose, ornithine and 
lysine but not urea, lactose, citrate, indole and sorbitol (OIE, 2012). Various culture media used are Triple Sugar Iodine, Salmonella Shigella agar, McConkey agar, Motility Indole Ornithine, Simmons Citrate, Methyl red-Voges Proskauer and Eosin Methylene Blue (OIE 2012; Hossain et al., 2006).

Sero-typing is done reliably through an agglutination reaction of the cellular $\mathrm{O}$ antigen in Salmonella serotypes with anti O antigen-antibody. However, it cannot differentiate between closely related biotypes such as Salmonella pullorumand Salmonella gallinarum (Hossain et al., 2006; Brooks et al., 2008) while classical carbohydrate fermentation tests can differentiate. Salmonella pullorum cannot utilize dulcitol, maltose and lactose as carbon source and uses arabinose, dextrose and lysine as energy source (OIE 2012).

Apart from classical fermentation tests, PCR is an accurate tool to detect Salmonella serotypes. The Salmonella $r f b s$ gene, which encodes for paratose synthetase, an enzyme required in the final steps of biosynthesis pathway of O- side chain sugar is uniquely present on the Salmonella sero group (Devendra et al., 2005) and the nucleotide sequence varied according to bacteria. Fragment of $r f b s$ gene has polymorphic nucleotide sequence for Sallmonella gallinarum (SG) and Salmonella PCR technique based on the amplification of $r f b s$ gene where its variation used to distinguish two Salmonella serotypes. pullorum (SP). SP isolates has guanine and adenine residue at position 598 and 237, respectively whereas SG has adenine and guanine residues at 598 and 237 positions,respectively (Devendra et al. 2005). PCR amplificationdone by targeting the pairing of $598^{\text {th }}$ nucleotide. Because of this polymorphism, amplification is altered. The primer sequence with the forward primer, $r f b s \mathrm{~F}(5 \mathrm{~V}$-GTA TGG TTA TTA GAC GTT GTT-3V) complements bases 431 to 451 at this gene and the reverse primer $r f b s$ R(5VTAT TCA CGA ATT GAT ATA TCC-3V) complements bases 617 to 597. The primer used amplifies SP DNA only thus confirming that the bacterial DNA is of Salmonella pullorum (Devendra et al., 2005).

This study aimed to isolate Salmonella pullorum strains from different diseased samples followed by differentiation using biochemical tests and genomic investigation.

\section{MATERIALS AND METHODS}

In the present study, Salmonella pullorum bacteria were isolated from the liver samples during postmortem examination from chicken of Kathmandu(5), Lalitpur(5), Bhaktapur(3), Chitwan(10) and Kavre(7) districts. All bacterialcultures were performed at the Animal Health Research Division of NARC. The liver samples collected were preenriched in the peptone water to recover sub-lethally damaged bacteria (OIE 2012; Nordic Committee on Food Analysis 1999), and the selective enrichment media with high osmotic pressure, relatively lower $\mathrm{pH}$ and higher temperatures for enabling bacteria to multiply as compared with other gut bacteria. The collected samples were weighed, and 12 gm of each sample was placed in a conical flask containing $100 \mathrm{ml}$ of dehydrated peptone water medium (1:9) and incubated at $37^{\circ} \mathrm{C}$ for 24 hours for non-selective enrichment (OIE 2012). For selective enrichment, $0.1 \mathrm{ml}$ and $1 \mathrm{ml}$ of peptone water weremixed in $10 \mathrm{ml}$ Rappaport vassiliadis soya peptone broth medium at $37^{\circ} \mathrm{C}$ and $10 \mathrm{ml}$ Tetrathionate broth 
at $41.4^{\circ} \mathrm{C}$, respectively for 24 hours (OIE 2012). Bile salts in the media act as the selective agent to retard the growth of Gram-negative bacilli other than Salmonellae and inhibit Gram-positive organisms (Funk et al., 2000).Bacterial culture was made with one full inoculum loop on Brilliant Green Agar (BGA) and Xylose Lysine Deoxycholate (XLD) agar and incubated at $37^{\circ} \mathrm{C}$ for 24 hours (OIE 2012). Then subculture was made on Nutrient agar and incubated at $37^{\circ} \mathrm{C}$ for 24 hours. Isolates were confirmed to be Salmonella by biochemical tests on Triple Sugar Iodide (TSI) agar, Motility Indole Ornithine agar, Simmons Citrate agar, Methyl Red-Voges Proskauer test, MacConkey agar, Salmonella Shigella agar and Eosin Methylene Blue agar. Fermentation of sugars namely lactose, sucrose, mannitol, dulcitol, acid and/or gas production on glucose, fructose, xylose and arabinose incubated at $37^{\circ} \mathrm{C}$ for 24 hours were carried out. Serotyping of the bacteria was done by performing slide agglutination test of the bacterial suspension and antiserum(Pullorum Antigen, Stained Antigen Polyvalent, Charles River, USA).

\section{DNA extraction}

DNA was extracted by using phenol chloroform method (Wilson 2001; Edwards et al., 2004). Bacterial colonies were prepared on nutrient broth and incubated overnight. It was transferred to an Eppendorf tube and centrifuged, and the resultant bacterial pellet was resuspended in TE buffer, cell lysis was done by SDS and proteinase K under incubation at room temperature. An equal volume of phenol chloroform was added and centrifuged to the lysate. The aqueous layer was transferred in fresh tube, to which sodium acetate and iso-propanol were added gently and DNA wasallowed to precipitate. The DNA was centrifuged, washed with $70 \%$ ethanol and stored on TE buffer.

\section{PCR amplification}

For the PCR, master mix product name, primers (forwardand reverse) DNA and nuclease free waterwas mixed in PCR tubes in the proportionate amount. The reaction cycle was carried out in a thermo-cycler, initial denaturation was done at $94^{\circ} \mathrm{C}$ for 10 minutes, cycle was carried out at $94^{\circ} \mathrm{C}$ for 1 minutes, annealing was done at $46^{\circ} \mathrm{C}$ for 1 minute and extension was done at $72^{\circ} \mathrm{C}$ for 1 minute for 30 cycles. Final extension was done at $72^{\circ} \mathrm{C}$ for 5 minutes and stored at $4^{\circ} \mathrm{C}$. The amplified product was loaded on $2 \%$ gel and observed under UV documentation apparatus (Cha 2008; Gunaseelan et al., 2012).

\section{RESULTS AND DISCUSSION}

The bacterial culture observed during the initial period of isolation was turbid on peptone water with unpleasant odor. Dirty and murky broth was observed during the enrichment on TTB and RVS medium in addition tosmall black and pink colonies on the XLD and BGA plates. Moreover, the biochemical tests on Triple Sugar Iodide, Salmonella Shigella, Methyl Red showed positive and some negative results on Voges Proskauer, urease, citrate and Motility Indole Ornithine agar.The colonies showing positive biochemical tests were further subjected to classical fermentation tests. This showed dulcitol, lactose, maltose and sucrose negative, whereas, mannitol, glucose, dextrose and lysine positive. 
While serotyping, agglutination was observed confirming the isolated bacteria to be Salmonella that was further confirmed by PCR after amplification of $r f b s$ gene. In the present study, Salmonella pullorum bacteria isolated following standard protocols of preenrichment and enrichment on selective media (OIE 2012; WHO Global Foodborne Infections Network 2010). were selected for classical carbohydrate fermentation tests. Eventually those bacterial colonies which fulfilled the criteria of Salmonella pullorum were selected for PCR diagnosis using the $r f b s$ gene primer.

Eighteen out of 30 samples gave the amplified DNA band of $187 \mathrm{bp}$ and thus confirming that the bacteria identified in biochemical and fermentation tests are Salmonella pullorum (Fig. 1).The PCR result gave clear bands of $187 \mathrm{bp}$ on agarose gel under UV light indicating the presence of Salmonella pullorum bacteria. To our knowledge, this is the first reported study of molecular characterization of Salmonella pullorum in Nepal using PCR.

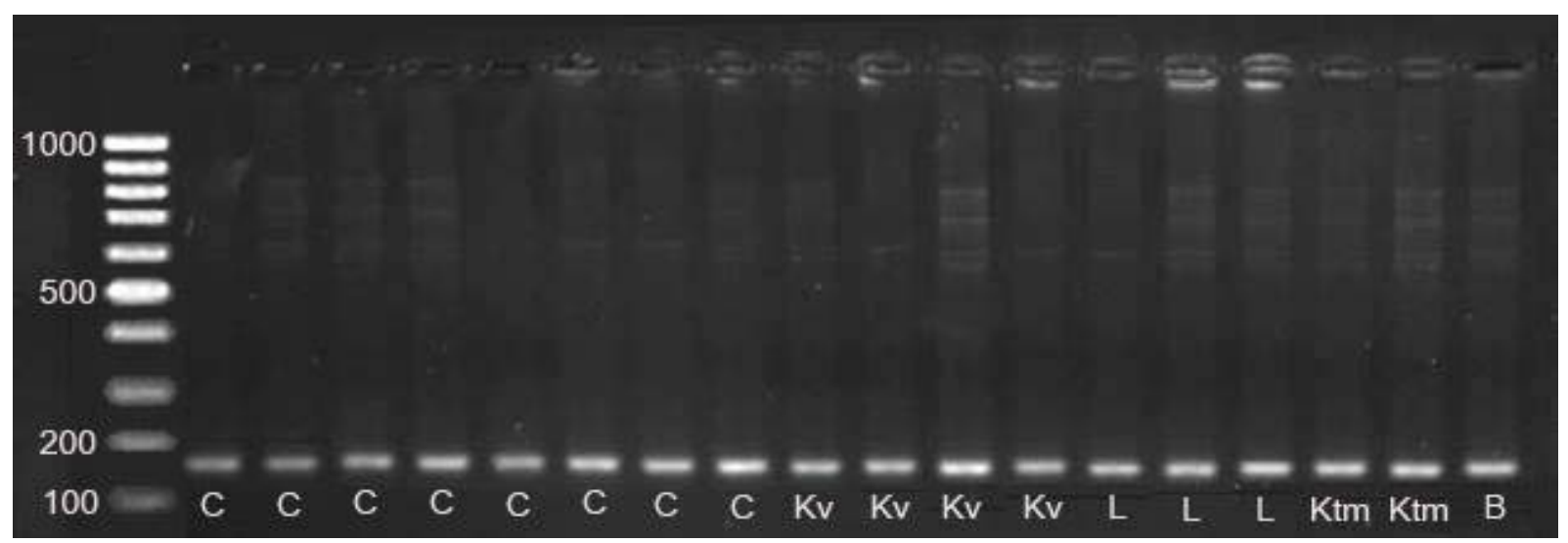

Fig1:Showing 187bp DNA bands of Salmonella pullorumisolated from 18 liver samples collected from Chitwan (C), Kavre (Kv), Lalitpur (L), Kathmandu (Ktm) and Bhaktapur (B).

\section{CONCLUSION}

Salmonella pullorum bacteria isolated from the infected liver samples from five different districts of Nepal were confirmed by biochemical tests and PCR amplification with demonstration of $187 \mathrm{bp}$ of amplified product.

\section{REFERENCES}

Brooks, B.W., Perry, M.B., Lutze-Wallace, C.L. and Maclean. L.L. (2008). Structural characterization and serological specificities of lippopolysaccharides of Samonella enterica serovar gallinarum biovar pullorum standard intermediate and variant antigenic type strains. Vet. Microbial. 126(4): 334-344.

Cha S., Jang D., Kim S., Park J. and Jang H. (2008). Rapid detection and discrimination of the three salmonella serotypes, S. Pullorum, S. Gallinarum and S. Enteritidis by PCR-RFLP of ITS and fliC genes. Korean J. Poult. Sci., 35(1): 9-13. 
Devendra, H.S., Park, J. Ho Mae Rim Cho, Myeong Cheol Kim and Joon Seok Chae. (2005). Allele-specific PCR method based on $r f b s$ sequence for distinguishing Salmonella gallinarum from Salmonella pullorum serotype specific rfbs sequence polymorphism. Journal of Microbiological Methods 60: 169- 177.

Edward, M., Arnscheidt, A., Kruger, A. Strompl, C. and Mau, M. (2004). Simplified protocols for the preparation of genomic DNA from bacterial cultures. Molecular Microbial Ecology Manual, Second Edition 1.01: 3-18.

Funk, J.A., Davies, P.R. and Nichols, M.A. (2000). The effect of fecal sample weight on detection of Salmonella enterica in swine faeces. J. Vet. Diagn. Invest.5:412-8.

Hossain, M.S., Chowdhury, H., Islam, M., Haider, G.and Hossain. M. (2006). Avian Salmonella Infection: Isolation and Identification of Organisms and Histopathological Study. Bangl. J. Vet. Med. 4(1): 07-12.

ISO 6579:2002(E) $4^{\text {th }}$ ed. Microbiology - General guidance on methods for the detection of Salmonella, International Organization for Standardization, Geneva, Switzerland.

Nordic Committee on Food Analysis (1999). Salmonella detection in food. NMKL Method No. 71, Second ed., Oslo, Norway.

WHO Global Foodborne Infections Network, 2010. Laboratory Protocol: Isolation of Salmonella spp From Food and Animal Faeces. Accessed on 2016/12/07.

Wilson, K. (2001). Preparation of genomic DNA from bacteria. Current protocols in molecular biology. 00: i: 2.4:2.4.1-2.4.5.

World Organization for Animal Health (OIE) (2012). Chapter 2.3.11. Fowl typhoid and Pullorum disease. In: Manual of Diagnostic Tests and Vaccines for Terrestrial Animals, Seventh Edition. OIE, Paris, France, 514-527. 